Ненад Д. Плавшић

Универзитет у Београду

Православни богословски факултет

Београд, Србија

nenadplavsic@gmail.com

DOI: 10.18485/rit.2022.20.37.5
UDK: 271.222(470)-726.1:929

Антоније, митрополит

Оригинални научни рад

Датум пријема: 28.9.2021.

\title{
МИТРОПОЛИТ АНТОНИЈЕ ХРАПОВИЦКИ У КРАЉЕВИНИ СХС/ЈУГОСЛАВИЈИ 1921-1936
}

\section{Резиме}

Руска емиірација или руско избейлишйво је збирни назив за стиановнике Руске

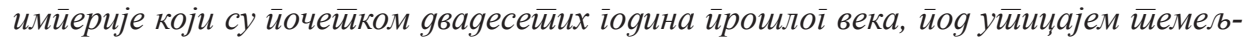
них йолитичких и ярушйвених йоиреса и иромена у Русији, расељени ио мноїим gр-

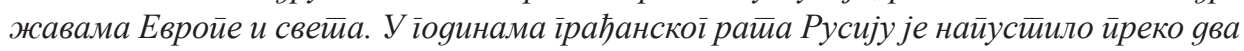

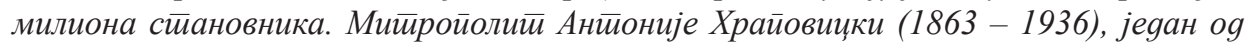

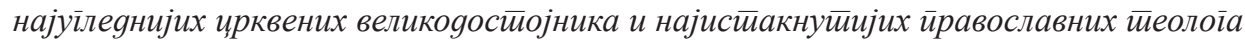
краја 19. и иррве йоловине 20. века, делио је иеешку суgбину руске емиірације. Послеg-

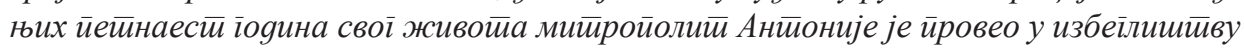

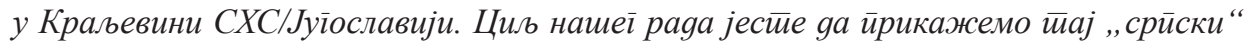

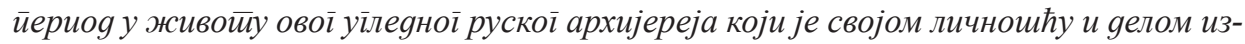
вриио уйицај на йојеgине исииакнуиее срйске йеолоїе.

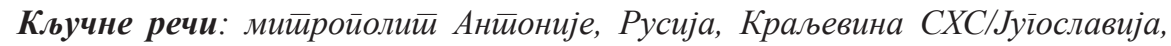
Руска Православна Заірранична Црква

\section{Увод}

Митрополит Антоније Храповицки (1863-1936) био је један од најугледнијих црквених великодостојника и најистакнутијих теолога краја 19. и прве половине 20. века. Некадашњи ректор три руске духовне академије, кандидат за сверуског патријарха 1917. године, митрополит кијевски и галицки и првојерарх Руске Заграничне Цркве је последњих петнаест година свог живота, од 14. фебруара 1921. до 10. августа 1936. године, живео у егизлу у Краљевини СХС/Југославији. Циљ нашег рада јесте да прикажемо тај „српски“ период у животу митрополита Антонија који ће потрајати све до његовог блаженог упокојења. 
Митрополит Антоније је делио тешку судбину руске емиграције која се почетком двадесетих година прошлог века, под утицајем темељних политичких и друштвених потреса и промена у Русији, раселила по многим земљама Европе и света. Стога је најпре потребно приказати сложене околности које су довеле до те емиграције и њене основне карактеристике по којима је то била спољашња, присилна, политичка и дугорочна емиграција.

Формирање Краљевине СХС хронолошки се подудара са великим и далекосежним променама у Русији. Прихват и смештај велике руске избегличке колоније и помоћ коју су Руси добијали у овој младој држави проистицала је из међусобних односа руског и српског народа који су се изражавали кроз историју почев од 12. века, а који су нарочит интензитет добили у 19. и 20. веку када је Русија давала подршку православним словенским народима у борби за стицање независности.

Неопходно је потом описати живот и рад митрополита Антонија у егзилу у Краљевини СХC/Југославији. Његова борба у изгнанству, као и за време живота у отаџбини, односно плодно пастирско и научно прегалаштво, као и племенитост у свеколиком јавном раду допринели су његовом угледу у новој средини.

На крају, видећемо на који начин је личност и рад овог угледног руског, али и свеправославног архијереја утицала на поједине српске теологе, његове савременике, који су писали поводом живота и рада познатог архипастира руског заграничја у нашој земљи.

\section{Феномен руског избеглиштва}

Руска емиграција или руско избеглиштво је збирни назив за специфичну скупину становника Руске империје која се почетком двадесетих година раселила по Европи и другим деловима света. Узроци који су довели до формирања ове групе становништва су: радикалне политичке и друштвене промене, идеолошка искључивост и војни пораз антибољшевичких оружаних снага у грађанском рату (Јовановић 1996: 17).

Главни покретач масовног и организованог исељавања Руса из отаџбине био је грађански рат до кога је дошло након државног удара који су бољшевици извели у Петрограду у ноћи између 25. и 26. окто- 
бра 1917. године. ${ }^{1}$ Грађански рат се водио између разних социјалних група на челу са бољшевицима и њихових противника (1918-1922). Борбу против узурпатора власти су повели поједини царски генерали руске армије у пролеће 1918. године и у лето исте године на три четвртине територије Русије формиране су групе и владе које су иступале против нове власти. У политичка превирања у Русији су се активно укључиле силе Антанте, чија је једна од чланица била и Русија, помажући материјално, морално и војнички царске генерале у борби против бољшевика. Совјетско руководство је организовало Црвену армију и прешло на политику ратног комунизма. Бољшевици су овој читавој борби дали класни карактер, на чему су посебно инсистирали њихови теоретичари. Према замислима њених појединих актера, ова борба требало је да се оконча потпуном елиминацијом са друштвене и политичке сцене противника који ће бити поражен. Стога је било свеједно хоће ли непријатељ бити прогнан или физички уништен ${ }^{2}$ (какав је био случај са последњим руским царем и царском породицОм). ${ }^{3}$

1 „У 10 сати ујутро 25. октобра (7. новембра) 1917. године Војно-револуционарни комитет при Петроградском Совјету радничких и војничких депутата известио је земљу о догађајима у престоници: 'Привремена влада је оборена. Државна власт је прешла у руке органа Петроградског Совјета радничких и војничких депутата - Војно-револуционарног комитета, који је на челу петроградског пролетеријата и гарнизона. Оно за шта се борио народ - неодложна понуда демократског мира, укидање власништва над земљом велепоседника, радничка контрола производње и стварање Совјетске владе - сада је осигурано. Живела револуција радника, војника и сељака!' Дела нове власти засад нису била у раскораку са њиховим декларацијама. У 22.45 часова 25. октобра (7. новембра), уочи јуриша на Зимски дворац, почео је са радом II Сверуски конгрес совјета. Од 650 депутата 390 су били бољшевици, 80 мењшевици и 80 есери. Од огромне већине људи из последње две партије у совјетима је остала само успомена. Конгрес је отворио свеприсутни Ф. И. Дан - учинио је то у име ВЦИК-а првог сазива. У том часу се у рукама побуњеника налазио већ читав град изузев Зимског дворца. У два ноћу следећег дана и дворац је био освојен а чланови владе ухапшени. Приликом преузимања власти у престоници је пало изненађујуће мало крви - Привремену владу, за разлику од њеног претходника, скоро нико није ни покушавао да брани. Приликом 'јуриша' на Зимски дворац - уместо чега би исправније било говорити 'запоседања' Зимског дворца - погинуло је пет нападача, док међу браниоцима није било губитака““ (Арјепатов 2017: 465-466).

2 Црвени терор је имао многе видове. Прва и најважнија брига историчара морају остати жртве тог терора чији број се не може тачно утврдити. Нема ни изгледа да ће икада бити утврђен, јер је сасвим извесно да је Лењин наредио да се архиви Чеке униште. Све што се са сигурношћу може рећи јесте да је Лењинов терор однео десетине, ако не и стотине хиљада живота. Жртве наредног таласа терора, који су лансирали Стаљин и Хитлер, бројаће се у милионима (Пајпс 2017: 791-792).

3 У ноћи између 16. и 17. јула 1918. године у Јекатеринбургу стрељани су бивши император Николај II Романов и чланови његове породице- супруга Александра и деца: Олга, Татјана, Марија, Анастасија и Алексеј. Егзекуторе је предводио Јаков Јуровски начелник је- 
Грађански рат у Русији је имао своје мене, периоде великих успеха белих армија, али и периоде њихове лоше организације и некоординираних акција у којима се Црвена армија консолидовала. Неколико страховитих контраофанзива Црвене армије, на чијем се челу налазио Лав Троцки, од марта 1919. до новембра 1920. године одлучило је о исходу рата. Један за другим битке су губили генерали Јуденич, Колчак, Деникин и Врангел, ${ }^{4}$ а након сваког од тих пораза из Русије су многи људи одлазили у избеглиштво.

Феномен руског избеглиштва, у односу на сличне политичке миграције, карактеристичан је из три разлога: 1) због своје масовности, јер је у годинама грађанског рата Русију напустило преко два милиона становника и то је најбројнија политичка емиграција у 20. веку; 2) заоштрена идеолошка конфронтација се овде први пут појављује као један од основних мотива и покретача исељеништва; 3) због високог постотка људи са универзитетским и средњим образовањем међу избеглицама, што се јавља као последица идеолошке искључивости по класној основи коју су заоштриле нове власти у Русији (Јовановић 1996: 25). Остале политичке емиграције, које су се у Европи појавиле каснијих година, нису имале ни приближну масовност, као ни интензитет који је имала руска емиграција.

\section{Руске избеглице у Краљевини СХС/Југославији}

У првој фази избеглиштва, док је још постојала нада за повратак у ослобођену отаџбину, руски емигранти су у веома високом проценту тежили концентрисању у државама које су се граничиле или гео-

катеринбуршке Чеке. Према званичном извештају Совјетског Савеза, цар Николај II Романов, његова породица и особље, погубљени су због претње да ће град окупирати Чехословачка легија (Јекатеринбург су 25. јула освојили Чеси). Заправо, убијени су највероватније планирано по налогу бољшевичких власти. У мемоарима написаним 1920. године, а објављеним тек 1989. године Јуровски је навео да је кодирана наредба за „истребљење“ Романових примљена 16. јула (Пајпс 2017: 731). Дана 1. октобра 2008. године, Врховни суд Руске Федерације је донео одлуку да су Романови били жртве политичке репресије, након чега су рехабилитовани. Осам година раније, 15. августа 2000. године, Руска Православна Црква је канонизовала царску породицу.

4 Петар Врангел (1878-1928) је у мају 1920. године постављен за врховног комаданта Руске армије. Након пада Крима евакуисао се у Константинопољ, а 1922. године је преселио свој штаб у Краљевину СХС. У Сремским Карловцима је 1924. године основао Руски општевојни савез који је објединио велики део учесника Белог покрета у емиграцији. Преселио се у Брисел 1927. године где је убрзо и умро. Његови посмртни остаци су 1929. године пренети у Краљевину СХC и сахрањену у Београду. 
графски биле близу Русије: Финска, Естонија, Летонија, Литванија, Пољска, Чехословачка, Немачка, Бугарска, Краљевина СХС, Кина односно Манџурија. Средином двадесетих година и касније, у другој фази, уочљиво је миграторно удаљавање од Русије, најчешће ка Француској, а потом и масовније прекоморско емигрирање (Јовановић 1996: 24).

У пролеће 1919. године појављују се прве групе руских избеглица из Одесе у Краљевини СХС. Од пролећа 1919. до лета 1921. године било је пет великих имиграционих таласа Руса, чије је полазиште у основи био југ Русије, који су дошли у Краљевину. Поред тога, доласци су се одвијали изван ових имиграционих таласа појединачно или у мањим групама. Процењује се да је до позне јесени 1920. године у Краљевину СХC дошло $41.000-44.000$ руских избеглица (Јовановић 2008: 160).

Прихват и смештај руских избеглица, као и помоћ коју су добијали од Краљевине, осим општег хуманитарног пружања помоћи унесрећеним људима, требало је да изрази захвалност српске круне и српског народа за помоћ од Русије током Првог светског рата: „Овакво понашање најчешће је тумачено као дужност која се мора извршити, без обзира на тешко стање у коме се читава земља налазила, док је, по тим тумачењима, сама обавеза проистицала из српско-руског савезништва, 1914-1918, а на општијем нивоу из словенске узајамности“ (Јовановић 1996: 44).

Посебност руске избегличке групе у Краљевини СХС проистицала је из међусобних односа који су се изражавали на следећим нивоима: 1) на нивоу званичних односа, јер се кроз специфичан однос власти Краљевине према избеглицама (идеја о „враћању дуга Русији“) преламао однос према СССР, што се одразило на специфичном организационом положају руских избеглица у односу на друге етничке групе у Краљевини; 2) на нивоу емотивних реакција кроз однос руских избеглица према Краљевини, коју су веома често дуго времена називали Србија, а у миграцијама унутар Краљевине тежили су ка источном делу земље итд.; 3) на нивоу свакодневног живота где је уочљив и посебно наглашен низ различитости: а) друштва и друштвених норми царске Русије и Краљевине СXC, б) навика, в) стилова живота, г) односа према власништву, д) доживљавања просторности и величине, ђ) образовања, е) еманципације, ж) тежњи ка модер- 
ном, з) дноса према традицији, и) односа према табуима, ј) у начину исказивања религиозности, к) испољавања и опште перцепције приватног (и интимног) живота (Јовановић 1996: 23).

Отворено инсистирање од стране Краљевине на признавању легитимитета избегличким органима власти као јединим представницима руског народа омогућило је формирање својеврсног избегличког центра у Сремским Карловцима где су били смештени Руски синод и Врховна војна команда чије ингеренције је признавала читава избегличка екумена. Отворена подршка избеглим Русима омогућила је и стварање засебног руског основног и средњег школског система на територији Краљевине. Такав однос Краљевине је истовремено био и један од начина истицања доследности у непризнавању новог режима у СССР (Јовановић 1996: 44).

Делатност руских избеглица је била значајна у многим аспектима живота међуратне Југославије. Значај њихове делатности може се посматрати кроз допринос у четири области: 1) најзначајнији начин на који су Руси оплемењивали, обогаћивали и образовали средину у којој су се затекли је лично ангажовање појединаца у научним и културним институцијама и културном животу уопште; 2) допринос Руса економском развоју међуратне Југославије је био двојак. Њихови истакнути архитекти, инжењери и лекари видно су допринели како појединачним ангажманом на великим пројектима тако и радом у многим институцијама. Колективни допринос Руса огледао се у томе што је Краљевина ангажовала делове армије генерала Врангела за обављање тешких и компликованих послова на изградњи магистралних путева и железничких пруга; 3 ) сарадња југословенских научника са руским колегама, од којих су неки били светски признати научници, као и формирање Руског научног института оставило је видног трага на друштвеној сцени Краљевине због употребе њиховог знања у конкретним пословима који су им били поверавани од стране државе и штампању научних радова који су на овим просторима по први пут отворили неке проблеме; 4) велики број руских интелектуалаца различитог профила (међу којима се налазило девет научника који ће током тридесетих година постати чланови Српске краљевске академије, али што је можда било још значајније и преко шестсто учитеља и професора) попунило је велику празнину која је настала пре свега у српском, али и у југословенском друштву, привреди и науци као по- 
следица великог страдања у Првом светском рату. Стога је појава руских избеглица представљала јак друштвени импулс једном измореном друштву, пре свега током двадесетих година, док није стасала прва генерација домаћих кадрова (Јовановић 1996: 44-46).

Постојале су бројне организације које су помагале друштвено самоорганизовање руских избеглица. Међу њима су се истицале оне чије је поље рада обухватало читаву избегличку екумену и које су имале своја представништва и представнике у свим државама у којима је било руских избеглица. Две од њих, несумњиво најзначајније установе избегличког света, имале су свој центар у Краљевини СХС/Југославији: Руска Православна Загранична Црква (1920-1944) и Руска армија (1920-1926) (Јовановић 2008: 160). Црква је симболизовала духовне везе избеглих људи са традицијама нестале Царске Русије.

\section{Живот и рад митрополита Антонија Храповицког у егзилу}

Грађански рат и револуционарни друштвени преображаји у Русији су отежали организационо функционисање Цркве. Устројство Руске Цркве је било измењено на Сабору 1917-1918. године, јер је одлучено да се изабере патријарх чиме је укинута двеста година стара одлука Петра Великог да Свети синод представља највишу инстанцу црквене власти. Услед грађанског рата 1919. године дошло је до нарушавања нормалне комуникације између црквене администрације на територијама под командом антибољшевичких снага са новоизабраним патријархом Тихоном у Москви. Због такве ситуације на југу земље је формирана Привремена виша црквена управа ${ }^{5}$ на чијем се челу, као најстарији и најутицајнији међу архијерејима, нашао митрополит кијевски и галицки Антоније Храповицки, један од тројице кандидата за патријарха. ${ }^{6}$ Током грађанског рата митрополит Ан-

5 Привремена виша црквена управа на југоистоку Русије формирана је на Сабору у Ставропољу Кавкаском који је одржан од 19. до 24. маја 1919. године. На том Сабору је одлучено да Привремена виша црквена управа има сву пуноћу црквене власти на југоистоку Русије до успостављања везе са патријархом, коме ће бити предат извештај о свему предузетом од ње. Привремена виша црквена управа југоистока Русије била је практично потпуно самостална црквена управа у односу на патријараршку управу у Москви (Пузовић 2012: 29-30).

6 „Раније, 30. октобра, Сабор је саслушао извештај о начинима избора за патријарха. Као пример су узели правила која су постојала у Константинопољској Цркви, и прво су гласали за кандидате за патријарха, које је могао да изабере цео Сабор (епископи, свештеници и лаици). Као резултат тога, од 25 кандидата, које су предложили чланови Сабора, већи део гласова (101) је добио архиепископ Антоније (Храповицки). Ново гласање се одиграло 
тоније је био у пољском заробљеништву, а после ослобађања стаје на чело Привремене више црквене управе југоистока Русије (Пузовић 2012: 37).

После пораза армије генерала Врангела Привремена виша црквена управа је заједно са цивилима напустила земљу и избегла у Константинопољ. Патријарх Тихон, Свети синод и Виши црквени савет су 20. новембра 1920. године донели Указ о стварању привремених црквених управа под руководством најстаријег јерарха на територијама које су отцепљене од Централне црквене управе. Тај акт је представљао кључни канонско-правни документ на основу кога је функционисала Привремена виша црквена управа у избеглиштву. По доласку у Константинопољ, руски јерарси су се обратили чувару Васељенског престола митрополиту Доротеусу да им дозволи да, на територији под његовим старањем, наставе да опслужују руске вернике. Митрополит Доротеус им је 29. децембра 1920. године дао благослов да наставе са радом. Тада је потврђен састав Више црквене управе коју су сачињавали: председник митрополит кијевски и галицијски Антоније и чланови митрополит херсонски и одески Платон, архиепископ кишињевски и хотински Анастасије, архиепископ полтавски и перејаславски Теофан и епископ севастопољски Венијамин (Јовановић 2006: 320).

У марту 1920. године митрополит Антоније је напустио Русију и провео извесно време на Светој Гори. У септембру 1920. године је на позив генерала Врангела дошао на Крим. ${ }^{7}$ Већ у новембру исте го-

31. октобра након што је било разјашњено да је немогуће изабрати А. Д. Самарина за патријарха, с обзиром да је био лаик. Тада су чланови Сабора (у гласању је учествовало 309 чланова) у својим цедуљама истицали не само име једног кандидата, већ три. Као резултат тога, већину (159 гласова) је поново добио архиепископ Антоније (Храповицки), који је био признат за првог кандидата за патријарха. Након поновног гласања, такође је био изабран архиепископ Арсеније (Стадњицки) који је добио 199 гласова. А у трећем кругу гласања за кандидата су изабрали митрополита Тихона (Белавина), који је добио 162 гласа. На тај начин, у улози кандидата за патријарха Сабор је изабрао архиепископе Антонија и Арсенија, као и митрополита Тихона. Да су епископи искористили своје право да бирају кандидата за патријарха, онда би, несумњиво, првојерарх постао архиепископ Антоније. Али архијереји су одбацили то право, одлучивши да се патријарх изабере посредством жреба““ (Фирсов 2008: 491-492).

7 Генерал Врангел је на следећи начин размишљао у коју државу би се могло поћи у избеглиштво: „Уколико будемо морали да напустимо родну земљу, тешко да бисмо могли рачунати на саосећање других земаља. Ниједна од њих, вероватно, не би пристала да нам пружи уточиште. Изузетак су могле чинити словенске земље, а понајпре Србија, која толико дугује Великој Русији. Ја сам српском краљевићу Александру упутио писмо у коме га молим да нам пружи уточиште и заштиту у случају несреће. Писао сам да чиним све могуће како бих од црвеног јарма спасао последње парче руске земље и да желим да верујем да ће ми Господ 
дине митрополит Антоније је био приморан да заувек напусти Русију и да са својом паством носи све терете изгнанства. У фебруару 1921. године на позив патријарха српског Димитрија, Привремена виша црквена управа је прешла у Краљевину СХС. Тада је у Србију дошао митрополит Антоније Храповицки ${ }^{8}$ који је пре тога живео кратко време у Атини, затим у Цариграду. ${ }^{9}$ Убрзо по доласку у Србију 13. децембра 1921. године митрополит Антоније је одликован Орденом Светог Саве I степена (Пилиповић 2018: 56). Боравећи у Сремским Карловцима на дан своје Крсне славе светог апостола Андреја Првозваног, краљ Александар Карађорђевић је скинуо са себе орден светог Саве I реда и својеручно га заденуо митрополиту Антонију на груди (Арсењев 2013: 45). ${ }^{10}$

Српска Православна Црква је после Првог светског рата важила за водећу словенску православну Цркву која је могла да буде ослонац руској црквеној емиграцији (Пилиповић 2018: 14). ${ }^{11}$ У српској среди-

у томе помоћи, али ја, ипак, морам предвидети и оно најгоре (Петар Николајевич Врангел, Сећања, превод: Никола Миљковић, Логос-Графичар, Београд 2019, 258).

8 Митрополит Антоније је у нашу земљу стигао 14. фебруара 1921. године из Цариграда преко Свете Горе (Ђурић 1990: 22).

9 „За време краткотрајног боравка у Цариграду 11 (24.) јануара 1921. године Владика је замонашио свог Феђу са именом Теодосије у част великог испосника Кијевопечерског, и рукоположио га за јеромонаха. Следећих 16 година отац Теодосије и нема своју биографију - она је уткана у биографију Владике Антонија. После смрти свог Великог Аве, архимандрит Теодосије је једно време руски парох у Сремским Карловцима, а затим на инсистирање патријарха Варнаве и на позив епископа Митрофана, блиског сарадника митрополита Антонија, духовника и управника Монашке школе у Дечанима, постаје прво сабрат, па старешина Царске Лавре Високи Дечани. У априлу 1941. године после слома југословенске војске, када су разуларене балистичке банде опколиле ту древну српску светињу, архимандрит Теодосије неустрашиво излази пред њих и убеђује да се разиђу дајући тиме времена сабрату јеромонаху Макарију (потоњем старешини Дечана) да иако рањен одјури у Пећ по помоћ, па тако Лавра буде спашена од разарања и пљачкања. 1957. године он изненада умире у 61. години живота и с благословом администратора Епархије рашко-призренске епископа жичког Германа (сада Свјатејшег Патријарха) буде пренет у Београд и сахрањен у крипти Руске Иверске капеле на Новом гробљу занавек крај свог Аве“ (Тарасјев).

10 О великом поштовању краља Александра према мирополиту Антонију сведочи и следећи догађај: „Једном приликом, кад је у Карловце стигао Њ. В. Краљ Александар, затекао је у једној од алеја у парку Патријаршије Митрополита у колицима и Патријарха Варнаву како гура ‘возило'. Краљ је (мимо свих прописа) прво тражио благослов од Владике Антонија, а после од свог Патријарха!“ (Тарасјев).

11 Личност првог српског архиепископа Светог Саве, чијим залагањем је Црква у Србији стекла управну самосталност 1219. године, је веома значајна и за историјско датирање почетка односа Срба и Руса и везује се за први забележен контакт између ова два народа: „Врло је вероватно, према извештајима старе средњовековне српске књижевности, да је младог Растка, будућег Св. Саву, упутио у правцу монашког живота један руски калуђер. Та година сусрета Св. Саве са Русима (1185) сматра се често као прва година сусрета Руса и Срба уопште после раздвајања у прасловенско доба оних словенских племена која су се касније 
ни, на канонском подручју Српске Православне Цркве био је формиран центар црквеног живота заграничне Русије. Основа за деловање руске црквене управе на канонској територији Српске патријаршије била је одлука Светог архијерејског сабора Српске Цркве, од 31. августа 1921. године, која представља одговор на представку митрополита Антонија о преласку поменуте црквене управе на територију Српске Цркве. У одлуци Светог архијерејског сабора се истиче спремност Српске Цркве да се као и до сада стара о избеглом руском народу и његовим духовним потребама. Одлучено је да делокруг овлашћења руске заграничне црквене управе обухвата: 1) јурисдикцију над руским свештенством, у земљи и иностранству, које није у парохијској и државно-просветној служби и над војним свештенством у руској армији које није у српској црквеној служби; 2) бракоразводне спорове руских избеглица. Овом одлуком и благословом српског патријарха, 3. октобра 1921. године, управа над руским црквеним општинама у Краљевини СХС предата је митрополиту Антонију Храповицком (Пузовић 2012: 43).

У Сремским Карловцима је било смештено седиште синода Руске Православне Заграничне Цркве. Пре него што се трајно настанио у Патријаршијском двору у Сремским Карловцима митрополит је једно време боравио као гост патријарха Димитрија у згради старе Митрополије у Београду ${ }^{12}$ где је често служио у свечаној сали Треће му-

претворила у руски и српски народ. Али држимо да је тих додира било и много раније“ (Јелачић 2018: 373). Поједини догађаји из касније историје сликовито сведоче о изузетно блиским односима Српске и Руске Цркве и међусобном духовном прожимању српског и руског народа: „Тако је Сава Владиславић, један од истакнутих Срба у руској служби у време Петра I, на новој граници између Руске империје и Кине, у чијем је регулисању сам учествовао, подигао храм посвећен Св. Сави Српском. Симболика подизања руског храма посвећеног српском светитељу на руској територији генерално се уклапа у православно поимање вере, али и у руску политику и идеологију помагања и подржавања православних народа на Балкану и њену конкретну помоћ српској цркви“ (Јовановић 2012: 101).

12 „Отприлике у ово време, тј. када талас избеглица поче да запљускује Београд и остале градове Србије, митрополит Антоније се мање-више за стално пресели у Београд, где му покојни патријарх српски Димитрије стави на располагање стан у једној од соба старе Патријаршије. Уствари, њу су тада и даље звали митрополијом. Ово је била зграда још из времена кнеза Милоша, накривљена, не тако удобна и крајње формална изгледа. У дворишту ове куће налазила се још и мања кућа, попут старе колибице, али која, по свој прилици, у наше време већ није постојала, а са којом су били повезани мрачни догађаји из српске историје. У овој кућици једно време налазило се тело, по наређењу кнеза Милоша, убијеног јунака и вође Првог устанка, чувеног Карађорђа, оснивача династије Карађорђевића. Предање каже да је овамо у врећи било донето тело и засебно глава Црног Ђорђа. У овој Митрополији (порушеној приликом градње нове Патријаршије 1931. године), у левом крилу у приземљу, у последњој соби од улаза, долазио је и дуго времена живео митрополит Антоније са својим чу- 
шке гимназије код оснивача и старешине те Руске Цркве протојереја Петра Беловидова (Тарасјев).

Већ у јулу 1921. године у Сремским Карловцима је одржан први састанак Више црквене управе уз учешће великог броја архијереја. ${ }^{13}$ Услед нагомиланих практичних и организационих проблема везаних за црквени живот и делатност у изгнанству од 20. новембра до 2. децембра 1921. године у Сремским Карловцима је одржан Први Сабор Руске Цркве у заграничју. На Сабору су поред двадесет и четири епископа учествовали и други представници клира, као и мирјани. Сабором је председавао митрополит Антоније. Расправљана су бројна практична и организациона питања која су се тицала функционисања Цркве у избеглиштву. Сабор је, после прегласавања донео две посланице. Прва посланица је била упућена верницима Руске Цркве у расејању и изгнанству, а друга посланица мировној конференцији у Ђенови која је била у припреми и на коју су били позвани и совјетски представници. У тој посланици Сабор се заложио за обнову монархистичког друштвеног уређења у Русији и апеловао на владе најмоћнијих држава света да помогну оружану борбу против бољшевика (Јовановић 2005: 73-74). Обе посланице су биле усвојене под снажним утицајем монархистичких кругова и уз подршку митрополита Антонија, упркос противљењу дела архијереја предвођених архиепископом Евлогијем који су сматрали да се на тај начин Црква меша у политичка питања (Пузовић 2012: 44). Архимандрит Кипријан Керн је у свовеним келијником Феђом, тада још јерођаконом Теодосијем, а затим јеромонахом и архимандритом“ (Керн 2018: 14-15).

13 „Мора се истаћи да Владика није био први од руских јерарха који су нашли уточиште под окриљем Српске цркве: у фебруару 1920. године у Београд је стигло 5 Владика евакуисаних из Новоросијска. Били су то: архиепископ Евлогије, архиепископ Мински Георгије, епископ Сумски Митрофан, епископ Чељабински Гаврил и епископ Аполинарије. Бивши руски амбасадор у Србији В. Штрандман заузео се за њихов смештај по манастирима, чему су много допринели Митрополит Српски Димитрије и регент Александар. За непуну годину у Југославију су још стигли: архиепископ Полтавски Теофан, епископ Александровски Михаил, епископ Севастопољски Венијамин, епископ Курски Теофан, епископ Черноморски Сергије, епископ Јекатеринославски Гермоген, док су у време седница Сабора ту боравили и Архиепископ Кишињовски Анастасије, епископ Љубенски Серафим, епископ Царицински Дамијан, архиепископ Фински Серафим, митрополит Платон, Теофило и Мелетије, Архиепископ Нестор, епископ Димитрије. Митрополит Антоније је морао да прими на себе тешко бреме руковођења Руском црквом у изгнанству јер је схватао да само Црква може бар некако ујединити и пружити утеху толиком броју унесрећених. А било их је расутих широм света од пустог ужареног сабирног центра Галипољи у Малој Азији па све до плантажа Уругваја и Аргентине до рудника у Немачкој и фабрика у Јапану - близу 2 милиона. И само је ауторитет такве једне личности каква је био Митрополит Антоније могао сачувати јединство напаћене и разједињене пастве“" (Тарасјев). 
јим мемоарима, поводом несугласица на Првом Карловачком Сабору, записао: „За време Сабора руских православних епископа, представника свештенства и лаика који су се задесили у емиграцији, а који је одржан у Сремским Карловцима 1921. године, архиепископ Евлогије је заједно са тридесет три члана Сабора поднео писану изјаву о томе да постављање питања монархије, са помињањем династије, носи политички карактер и да као такво не подлеже разматрању црквеног сабора. Насупрот овоме, митрополит Антоније је тврдио да 'питање династије није политичко, већ чисто црквено’. Мишљење епископа на Сабору поделило се на два скоро подједнака дела, али је већина лаика подржала митрополита Антонија.“ (Керн 2018: 37). Испоставило се да су чланови Монархистичког савета у Сремским Карловцима наступили као добро припремљена група. Победи монархиста на Првом Карловачком Сабору умногоме је допринела потпуна попустљивост митрополита Антонија““ (Арсењев 2013: 49-51).

Истицање овако радикалне политичке позиције постало је кључни фактор и генератор свих будућих неспоразума и подела у Руској Цркви. Патријарх Тихон је 22. маја 1922. године указом захтевао од архијереја у Сремским Карловцима да укину Привремену вишу црквену управу у заграничју. Поштујући вољу патријарха они су то и учинили 13. септембра 1922. године, али су на истој седници основали Архијерејски синод Руске Православне Заграничне Цркве. Тако је унутар Руске Цркве у канонско-правном погледу настала веома сложена ситуација (Арсењев 2013: 74).

Потом је 1927. године дошло до потпуног прекида односа црквених власти у Сремским Карловцима са централном црквеном управом у Москви. Заменик чувара патријаршијског престола митрополит Сергеј Страгородски је 29. јула 1927. године упутио посланицу којом је захтевао од синода у Сремским Карловцима (чију је канонску ваљаност иначе негирао) и уопште од духовника у избеглиштву да се у својој друштвеној делатности писмено обавежу на пуну лојалност совјетским властима. Поводом тог предлога, који су јерарси у избеглиштву окарактерисали као неканонски и веома штетан за Цркву, сабор Руске Православне Цркве у заграничју под председништвом митрополита Антонија Храповицког је 9. септембра 1927. године донео одлуку да је „Загранични део Сверуске Цркве дужан да прекине односе са Московском црквеном влашћу због немогућности одржавања 
нормалних односа са њом и због њеног поробљавања од стране безбожне совјетске власти“ (Арсењев 2013: 76).

За кратко време долази и до новог раскола у Руској Цркви који је поново изазван политичким мотивима и сукобима. Митрополит Евлогије Георгијевски, који је управљао Руском Црквом у западној Европи и од 1926. године био у расколу са карловачком управом Руске Заграничне Цркве тако што је заједно са митрополитом у Северној Америци Платоном одбио да се потчињава решењима Архијерејског синода у Сремским Карловцима, је 1930. године одлучио да пређе под јурисдикцију васељенског патријарха. Митрополит Евлогије и његови викарни епископи су од 1927. године стављени под забрану свештенослужења од стране Сабора заграничних епископа у Сремским Карловцима, али они нису прихватали ове одлуке (Керн 2018: 37).

За време живота митрополита Антонија Храповицког расколи у Руској Цркви су годинама бивали све дубљи и уочљивији. У новембру 1935. године је карловачки Архијерејски синод осудио као јеретичко учење оца Сергеја Булгакова, а у фебруару 1936. године митрополит Евлогије је дефинитивно прекинуо све односе са Руском Православном Заграничном Црквом (Керн 2018: 77).

Руска црквена општина је 25. септембра 1927. године у Београду прославила јубилеј тридесетогодишњице епископске службе митрополита Антонија, на тај начин подсећајући на његову биографију и заслуге за Цркву. Та прослава се подударила са десетогодишњицом бољшевичких прогона Руске Цркве и била је својеврсни одговор у овом „рату јубилеја“. У очима Срба овај јубилеј митрополита Антонија је давао следећу поруку: „Руска емиграција, и ако је партаична и поцепана, сматра га за свог духовног вођу - неки можда чак и преко своје воље - јер он својим дубоким и проницљивим умом ужива ауторитет књижевника и научника, беседника, строгог православца и ретког зналца црквеног устава и канона, који, сем тога, воли свој народ и ради за његово добро““ (Пилиповић 2018: 56).

Митрополит Антоније је имао велики морални утицај на омладину коју је искрено волео и често позивао код себе на разговоре уз чај. Он је и у избегличким условима наставио своју мисију привлачења младих људи у Цркви: „Из ‘Антонијевог гнезда’ изађоше Свети Владика Јован Шангајски (кога је он запазио још као младића у Харкову), Схиархимандрит Амвросије духовник Миљковски; Архимандрит 
Кипријан (Керн), професор Свето-Сергијевског института у Паризу, игуман Лука Миљковски и Тумански, протојереј-мученик Владислав Некљудов, (убијен 1949. године у сарајевским казаматима), Архимандрит Спиридон (Јефимов), јеромонаси Макарије, Лонгин, Андреј (потоњи епископи Српске Цркве), браћа Бартошевичи (потоњи Епископ Леонтије и Архиепископ Антоније), јеромонах Антоније (Сјенкевич) потоњи Архиепископ Лос-Анђелески, Архимандрит Силуан (Стрижков), протојереји и професори: Борис Волобујев, Борис Селивановски, Виталије Тарасјев, Борис Критски и многи, многи други. Ипак (како сведочи Петар Лопухин, познати црквени публициста, веома близак Владици), он је једном приликом изјавио да су му 'по духу најближи Отац Јован и Отац Амвросије’ (Св. Владика Шангајски и духовник Миљковски)“ (Тарасјев).

Свети синод Руске Православне Заграничне Цркве у Сремским Карловцима је одобрио митрополиту Антонију титулу „Његово Блаженство“. Та титула је дошла и са одобрењем српског патријарха Варнаве, који је поводом другог јубилеја митрополита Антонија (педесетогодишњице) интензивирао своју црквено-дипломатску активност настојећи да се у црквеним фракцијама руске емиграције нађе заједнички језик (Пилиповић 2018: 57). Уз посредство српског патријарха Варнаве започели су преговори између Карловачког синода и Западноевропског егзархата. У пролеће 1933. године у Београду дошло је до „помирења“ митрополита Антонија и митрополита Евлогија који је допутовао да моли опроштај. Присутни су се дуго сећали овог дирљивог догађаја: „Два стара архијереја леже крај ногу један другога, моле за опроштај и траже да се над сваким од њих прочита разрешна молитва. Заиста, сцена из патерика древних времена“" (Керн 2018: 60). У новембру 1935. године на Сабору у Сремским Карловцима донета je „Привремена одлука“ коју је митрополит Евлогије потписао уз напомену да она треба да буде одобрена од Епархијског савета у Паризу и потврђена од стране Васељенског патријарха. Евхаристијска заједница између „карловчана“ и „евлогијанаца“ је била поново успостављена, иако Епархијски савет који је митрополит Евлогије сазвао није потврдио „Привремену одлуку“. Након помирења са митрополитом Евлогијем, митрополит Антоније због своје болести практично није узимао учешћа у разматрању проблема који су узроковали поделе међу црквеним општинама у дијаспори (Керн 2018: 104-105). 
Митрополит Антоније Храповицки се упокојио у Господу 10. августа 1936. године у Сремским Карловцима. Вест о смрти угледног архипастира руског заграничја је била медијски пропраћена, ${ }^{14}$ a већ 1936. године одржавани су комеморативни скупови. Опело је служено 12. августа у саборној цркви у Београду. Архимандрит Кипријан Керн је следећим речима описао сахрану свог духовника митрополита Антонија: „Опело је било невероватно дуго. Служио је патријарх Варнава, уз саслуживање шесторице архијереја, међу којима је био и архиепископ Анастасије, и више од двадесет свештеника. Патријарх је ушао у цркву пре литургије у осам часова ујутру, а митрополитово тело је изнето у четири часа поподне. Ништа није било изостављено из чина опела. Појале су две певнице, велики хор, састављен из свих цркава, под диригентском палицом Маслова, и посебан свештенички и студентски хор у којем су појали и студенти и професори Богословија, али и сви који су хтели да поју. Појали су са канонархом, понављали два и три пута, једном речју, типикари су радили како им је воља. Било је толико много људи у храму да ако би неко и изгубио свест, не би могао да падне: није имало где да се падне... Литија је ишла кроз читав град до руске цркве, где је одслужен помен, а затим на Ново гробље, где је испод Иверске капеле сахрањен митрополит“ (Керн 2018: 110-112). Помен је служен у руском храму на Ташмајдану који је по жељи митрополита Антонија био посвећен Светој Тројици 1924. године (Тарасјев). После помена, литија је кренула пут Новог гробља, где је у крипти Иверске капеле сахрањен митрополит Антоније Храповицки.

Руској Православној Заграничној Цркви у Сремским Карловцима, која је штампала претежно богослужбене књиге, штампана делатност није била страна, јер је њен поглавар митрополит Антоније био познати богословски мислилац и писац (Ђурић 1990: 184). У Сремским Карловцима, Новом Саду и Београду штампано је много радова митрополита Антонија Храповицког. Његов богословски рад је и у избеглиштву био разнолик и плодотворан. За време боравка у нашој земљи он пише низ расправа о питањима православља, катихизиса и догмата. Нека од његових у нашој средини штампаних дела су: Разі̄o-

14 Кипријан Керн сведочи да је за митрополитово упокојење сазнао из издања Политике од 11. августа 1936. године са великим натписом: „Умро митрополит Антоније“ (Керн 2018: 108). 


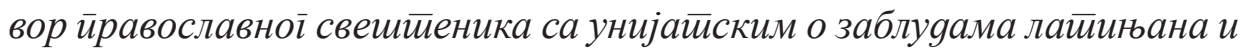

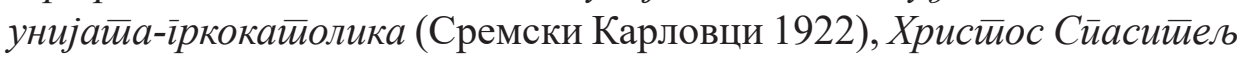
и револуција (Београд 1922), Је ли Христиос био космойолити или нащионални йайриот̄ (Нови Сад 1923). Искустиво хришћанской иравославної кайихизиса (Сремски Карловци 1924), Доімма о искуйљељьу (Сремски Карловци 1926), Пушкин, каква морална личносии и иравославни хришћанин (Београд 1929), Нови иристиуй Ренану (Нови Сад 1930), На раскрсници (1932), Васељенска, или ірчка, или руска, или арайска (Београд 1933). Постоје значајна дела митрополита Антонија у егзиу која су штампана и у другим државама: Речник уз gела Досйојевской:

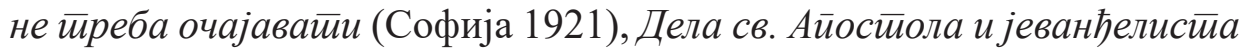
Јована Боіослова (Варшава 1928). У Софији је поводом обележавања педесетогодишњице свештеничког позива митрополита Антонија изашла репрезентативна књига Зборник изабраних gела. После Другог светског рата у Њујорку је његов одани ученик архиепископ Никон Рклицки штампао дела и биографију митрополита Антонија у 17 томова (Ђурић 1990: 231). ${ }^{15}$

15 Јован Качаки је прецизно навео библиографске одреднице везане за радове, посланице и писма митрополита Антонија које су штампане у Краљевини: Брайское йосланіе къ русскому нарояу и воинстиву (1921), Посланіе Мировой Конферениіи ойъ имени Русскайо Всезаїраничкаїо Церковнаі̄о Собора (Сремски Карловци 1921), Бесеgы Православнаїо свя-

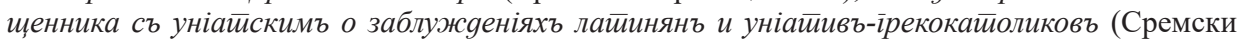
Карловци 1922), Бесеgа йравославнаїо съ уніайомъ: совершенно новое освещеніе войросовъ (Сремски Карловци 1922), Окружное Посланіе Собора Архіереевъ Русской Православной

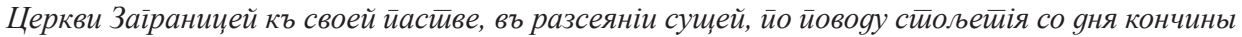
Прейоgобнаїо Серафима Саровскаїо Чудотивориа (Белградъ 1923), Преgисловіе, в: Маевскій, Вл: Нашъ Русскій Православный Пайріархъ (Белградъ 1923), Приміреніе: gоклаgъ ирреgстиавленный Предсеgаиелемъ Парламенииской Груййы, Мииройолийомъ Аниионіемъ въ засеgаніе

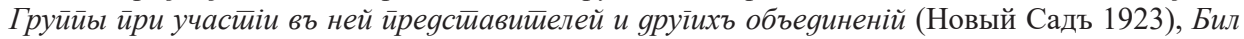

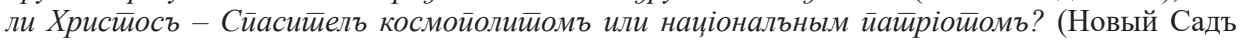
1923), Ойыйъ Христиіанскаїо Православнаїо Катиихизиса (Сремски Карловци 1924), Дої-

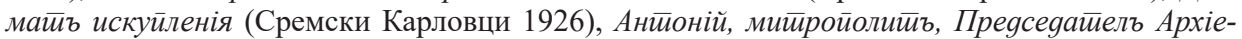

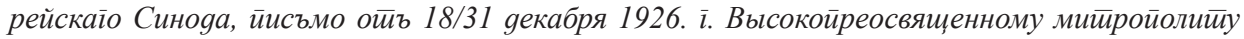
Евлойию (1926), Писъмо Высокойреосвященаїо Анйонія къ Высокойреосвященному Евлойию, въойвейъ на обращеніе еі̄о къ йасииве (Сремски Карловци 1926), Окружное Посланіе Архіерейскаїо Синоgа Рууской Православной Церкви Заїранищей (Сремски Карловци 1927), Пуикинъ какъ нравстивенная личностьъ и иравославный хрисииіанинъ (Белградъ 1929), Молъба ко всемъ Церквамъ Православнымъ (Новый Садъ 1929), Воззваніекъ Православныль Русскимъ люgям (Белградъ 1929), Новий йохоgъ къ Ренану (Новый Садъ 1930), Окружное Пасхалъное йосланіе Преgсеgайеля Архіерейскаїо Синоgа Русской Православной Церкви Зайраницей къ Православной Русской йасивве за рубежомъ (Сремски Карловци 1931), Посланіе Преgсеgаиеля Собора Архіерейскаі̄o Синоgа Русской Православной Церкви Заїраницей Блаженней-

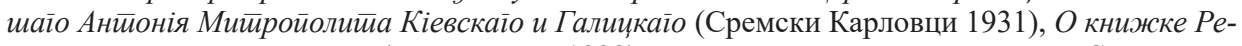
нана съ новой иочки зренія (Новый Садъ 1932), Чйо слеgуейъ разумейъ йоgъ „Сиасающей Верой“ (Белградъ 1932), На расйуйы (Белградъ 1932), Анйоній Мийройолийъ Кіевскійи Га- 


\section{Српски богослови о личности митрополита Антонија Храповицког}

\section{Митрополит Антоније Храповицки је био познат у српској сре-} дини и пре свога избеглиштва. Петар Росић, потоњи српски патријарх Варнава који је извесно време боравио на школовању у Русији, ${ }^{16}$ је 1900. године написао чланак „Преосвештени Антоније, епископ чистопољски, викарије казањске епархије и ректор Казањске духовне академије“" публикован у часопису Босанска вила-лисй за забаву, йоуку и књижсевности који је излазио у Сарајеву (Пилиповић 2018: 55).

Када је 1920. године успостављена јединствена Српска патријаршија четрдесетогодишњи Варнава Росић је 17. новембра изабран за митрополита скопског. Први епархијски часопис у Српској Право-

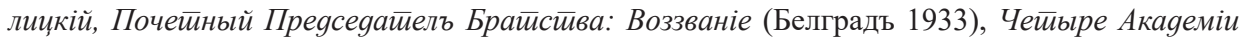
(Белградъ 1933), Вселенская или Греческая, или Российская, или Арабская (Белградъ 1933), Окружное Посланіе Собора Русскихъ заірраничныхъ Архиеревъ Православной Русской йа-

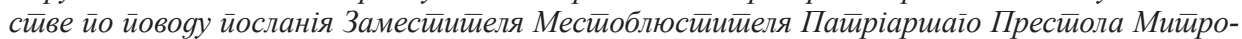
иолийа Серїя ойъ 23 марйа 1933 їоgа (Сремски Карловци 1933), Писъмо Преосвященному Лийовскому и Виленскому Елевиеерію (Сремски Карловци 1934), Блаженнейшій Аниионій

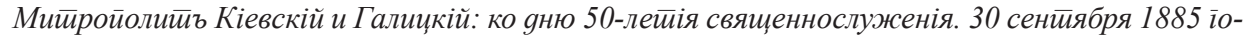
ga - 30 сенйября 1935 їоga, с авйоїрафом (Белградъ 1935), Сборник Избранных Сочиненій Блаженнейшеїо Аниионія, Мийройолийа Кіевскайо и Галицкоїо (Белградъ 1935), Размыиленіе о сиасийельной силе Хрисиовыхъ Сирастией (Белградъ 1937), О наученіи молийве: ииъсмо късвященнику о наученіи молиивве (Харков 1916, Сремски Карловци), Окружное Посланіе ко всемъ ирравославнылъ Пайріархамъ, Мииройолийамъ, Архіеиичскойамъ, Еииискойамъ, ирейоgобнымъ иресвитерамъ, инокамъ, инокиням и всемъ иравославнымъ хрисиітанамъ (Нови Сад), Православіе и шовинизмъ, Блаженнейшій Аниионій Митиройолийъ Кіевскій, Галиикій и всеі̄о зарубежъя: Біоїрафія, (С фотографіей), Appelatoutesles Eglises Orthodoxes (Нови Сад 1930) (Качаки 2003: 71-75).

16 О школовању будућег српског патријарха на Санкт-Петербуршкој духовној академији нема много података, јер његов студентски досије и кандидатски рад нису сачувани. Академију је уписао 1901. године. Његовој трајној везаности за Русију и Руску Цркву је допринела чињеница да се замонашио у Санкт-Петербуршкој духовној академији 1905. године. Постригао га је ректор Академије епископ Јамбургски Сергије Страгородски, будући Руски патријарх. Варнава је као Српски патријарх (1930-1937) пружао покровитељство Руској Заграничној Цркви и помагао у сређивању руских црквених прилика у емиграцији (Владислав Пузовић, Руски йуиееви срӣскої боїословља: иколовање Срба на руским яуховним акаяемијама 1849-1917, Православни богословски факултет Институт за теолошка истраживања-Службени гласник, Београд 2017, 378-381). О личности патријарха Варнаве Росића познати српски историчар Ђоко Слијепчевић записао је, између осталог, следеће: „Патријарх Варнава Росић (1930-1937) био је личност од видика и замаха... На трону српских патријарха био је свега седам година. Иако је то било кратко време да се учини нешто епохално може се, ипак рећи, да је он и за то време учинио доста. Он је водио цркву смело и одлучно и дубоко је поимао смисао времена у коме је деловао. Сав у српској државној и црквеној традицији, свестан и своје борбене прошлости и свога угледа у православном свету, патријарх Варнава је оgумирање срйске яржавностии йоgносио gосӣа йешко. И због тога се трудио да Српска црква, као и у прошлости, прими на себе све српске бриге, које су се као тамни облаци биле нагомилале са свих страна носећи у себи обести уништења“ (Слијепчевић 2018: 22). 
98 Ненаg Д. Плавшић: Мийройолий Анйоније Храйовиики у Краљевини СХС...

славној Цркви мирополије скопске Црква и живой - йоучни релиїиозно-йоиуларни часойис је обележио јубилеј тридесет година епископске службе и четрдесет година књижевног рада митрополита кијевског и галицког Антонија. У поменутом часопису који је излазио у Скопљу, у броју објављеном 1929. године, налазе се следеће речи митрополита Варнаве: „По вољи Божијој сад се налази митрополит Антоније у српској земљи, као наш гост. Српска црква дели с митрополитом Антонијем његов бол што је он далеко од своје рођене земље, што је у избеглиштву, али с друге стране не може да не изрази своју радост да је велики православни јерарх нашао склониште у српској земљи и у српској цркви... Радост имати у својој средини митрополита Антонија је радост ученика опет видети свога учитеља. Име митрополита Антонија познато је српском свештенству“ (Пилиповић 2018: 56-57).

У очима патријарха Варнаве Росића митрополит Антоније Храповицки је био личност која би требало да се стави у исти ред са великим јерарсима првих векова хришћанства. Он је следујући примеру древних светитеља, којима је подражавао у својим подвизима, био и религиозни и национални вођа руског народа (Росић 1936).

У нашем народу и Цркви су цењене велике заслуге митрополита Антонија за Руску Цркву и за јачање руско-српских односа у време када су се од Русије тражиле жртве ради остварења наших националних интереса (Јовановић 1936: 381). Стога је његова смрт доживљавана као ненадокнадив губитак: „Смрћу митрополита Антонија нестало је у руској цркви и православном свету једне крупне и заслужне личности, која је својим дугогодишњим и плодним научним, пастирским и јавним радом стекла велики углед и признање и ван граница руске народне цркве. Његова борба у изгнанству и племенита дела у свеколиком јавном раду дуго ће се спомињати, јер су утрли пут к васкрсу слободне и нове националне и православне Русије. А кад се то деси, у што је он био непоколебљиво уверен, његово животно дело биће достојно оцењено. Измучено руско избеглиштво изгубило је његовом смрћу много, а руска загранична црква највише“" (Јовановић М. 1936: 387).

Часопис Православног богословског факултета Универзитета у Београду Боіословље је 1939. године објавио панегирички чланак оца Јустина Поповића о митрополиту Антонију који је записано преда- 
вање одржано на комеморативној академији посвећеној успомени на блаженопочившег митрополита Антонија. У њему се један од највећих српских теолога двадесетог века скромно смирава пред тајном личности митрополита Антонија: „Ја се налазим у положају мрава који треба да говори о узлетима орла“ (Поповић 1939: 40). ${ }^{17}$ За Поповића митрополит Антоније је христољубац и христоносац чије се христољубље пројављивало кроз дирљиво човекољубље. ${ }^{18}$ Због своје истрајности у еванђелском христољубљу и благодатном човекољубљу он је велики подвижник наших дана и изузетна светоотачка појава у наше време (Поповић 1939: 41-42). Гледајући митрополита Антонија Храповицког млади Јустин Поповић је говорио себи да се и данас може живети светоотачки: „Он је свим бићем својим израстао из светих отаца. Отуда онолика дирљива љубав његова према светим Оцима: он није могао говорити о њима без умиљења и суза. Зато се и његова личност, и његов живот, и његов рад могу објаснити једино светим Оцима. Свети Оци су његови родитељи, његови учитељи, његови васпитачи, његови вођи. Они су га научили светости, они одушевили на подвижништво, они му дали васељенско осећање и сазнање православно. Подвизавајући се неуморно светоотачким подвизима, он је еванђелску љубав, и кротост, и смиреност, и милосрђе претворио у своју навику, у своју природу. А претворити Еванђеље у сво-

17 Поводом смрти митрополита Антонија отац Јустин Поповић је написао и један краћи текст који је објављен у часопису Хришћанска мисао 1936. године. У том тексту Поповић је написао да је блажени митрополит Антоније у овоме свету живео у заједници са светима и да је био мученик, исповедник, бесребреник, подвижник и молитвеник. Његовом смрћу се увећао број вечнобудних и неуморних молитвеника за наш јадни свет (Поповић 2007 : 354-356).

18 Кипријан Керн сведочи о томе да је митрополит Антоније био чистог срца попут детета: „Једном приликом је, у одсуству келијника Феђе, код митрополита дошао неки сиромашни руски питомац из Сарајевског корпуса. Био је без обуће, само у некаквим сандалама. Митрополит се сажалио и наредио да се погледа под креветом, не би ли се нашла било каква обућа. Пронашли су лепе, нове, високе чизме. Питомац је узео чизме са захвалношћу, обуо их и пошао у шетњу по граду у новим, модерним чизмама. Колика је била Феђина зачуђеност и нерасположење јадног митрополита када се испоставило да су то биле Феђине нове, прелепе чизме, које само што је био набавио. Међутим, то није био разлог за свађу или сцену између митрополита и његовог верног келијника. Први је био далеко изнад тога, а други је био као дете чистог срца, а затим је Феђа многима о томе говорио са певљивим, високим смехом, ударајући о своја колена“ (Керн 2018: 128). Керн је запазио и следеће: „Будући невероватно милостив и попустљив у односу према личном греху и паду по слабости (утицај Достојевског), он је био неумољив и до крајњих граница принципијелан и узак по питању конфесије и црквених канона. Управо овај однос према црквено-канонској дисциплини дефинисао је митрополитову позицију и у вези са проблемом такозваног заграничног раскола“" (Керн 2018: 57-58). 
100 Ненаg Д. Плавшић: Мийройолий Анйоније Храйовицки у Краљевини СХС...

ју природу - и јесте смисао човековог постојања у овом свету. У томе нам је блажени Митрополит незаменљиви учитељ и вођ““ (Поповић 1939: 42-43).

Поповић сматра да у новије време нико није снажније од митрополита Антонија утицао на православну мисао коју је скренуо са рационалистичко-схоластичког пута на благодатно-подвижнички пут (Поповић 1939: 44). Православље је благодатни живот и опит, а кроз то благодатно богопознање и човекопознање. Личност митрополита Антонија је од огромног значаја за цео православни свет, јер је он јединствена светоотачка појава нашег времена која је у светоотачком духу схватала васељенскост православља, јер је у његовој души било места за све православне: „Нико од наших савременика није тако еванђелски, тако светоотачки, тако православно схватио однос Православља према народностима као наш свети Владика, митрополит Антоније. Народ постоји да би се осветио и просветио вечном истином и вечним животом Православља. Оно што је велико и вечно у сваком народу јесте Православље, и у њему Господ Христос“ (Поповић 1939: 47).

Православна васељенскост прожима самосвест руског народа, јер његово самосазнање није ни расно, ни племенско, већ религиозно. Поповић истиче да Словени од браће православних Руса очекују следеће: „Да нас водите путем православне истине Христове; да нам будете истрајни вођи у остваривању вечних истина еванђелских; да нас водите к небу и небеској правди. Ви то можете, јер је света Русија дала безброј чудесних остварења и дивних оличења вечних истина православних“ (Поповић 1939: 49). Словенофилство митрополита Антонија, истиче Поповић, није било расно, већ еванђелски утемељено, односно засновано на служењу другима и смирењу пред Богом и људима. Православље је нова реч коју Словенство, на челу са светом Русијом, треба да објави свету.

Отац Јустин Поповић, који је митрополита Антонија редовно сретао за време његовог вишегодишњег боравка у Сремским Карловцима, ${ }^{19}$ исповеда: „Допустите, ја морам да се исповедим: иако Рус,

19 „Са прекидима, сретали су се од 1921. до 1936. године. Захваљујући митрополиту Антонију отац Јустин је, поред односа писмених текстуалних рецепција, успоставио однос и усменоі примопредавања духа руског Православља у регистре српске духовности“" (Лубардић 2009: 25). Митрополиту Антонију и Јустину Поповићу је била заједничка и љубав према великом руском писцу Фјодору Достојев- 
блажени митрополит је био стварни Владика моје душе, стварни Епископ - Надзорник мога срца. У њему - ја сам имао свог најмилијег духовника. Увек свеправославно настројен, он је нас, иностране православце, скупљао под широка крила своје велике руске душе, као што кокош скупља пилиће. Безброј пута ја сам осетио силу његове свеправославне љубави: за њега смо ми Срби били исто што и Руси. Из њега је излазила нека мила свеуједињујућа сила. Ја бих је назвао: православна васељенскост“" (Поповић 1939: 51-52). Стога српски народ треба да осећа велику захвалност што је једна таква личност својим дугогодишњим боравком у нашој средини осветила и оправославила нашу земљу.

\section{Закључак}

Руско избеглиштво у Краљевини СХС/Југославији представљало је сложену историјску и социјалну појаву која је била део знатно ширег миграторног процеса узрокованог одласком становништва из Совјетске Русије након револуционарних промена 1917. године и грађанског рата (1918-1922) који је био последица револуције. Радило се о појави која представља најмасовнију политичку емиграцију међуратног доба и која је, самим тим, задирала у све елементе живота избеглица и њиховог новог окружења као што су: политички, социјални, психолошки, културни и религијски. Српски народ је у складу са

ском. Јустин Поповић је много тога о овом славном писцу сазнао од митрополита Антонија Храповицког. Примера ради, сазнао је да су узори по којима је настао лик старца Зосиме били руски светитељ из осамнаестог века Тихон Задонски и свети оптински старци Амвросије и Макарије које је Достојевски походио (Храповицкий 1921: 182). Митрополит Антоније лично је видео Достојевског само једном због чега је више пута негирао мишљење које се однекуд појавило да је он послужио руском писцу као узор за лик Аљоше Карамазова: „За њега, младог Аљошу Храповицког, говорило се, несумњиво легендарно, да је послужио Достојевском у стварању лика Аљоше Карамазова. Пре монашења име митрополита Антонија је било Алексеј и тај Аљоша је као младић једном посетио Достојевског“ (Шаховској 2010: 106107). Кипријан Керн је посведочио о томе колико је важан митрополиту био Достојевски тако што је навео део њиховог разговора: 'Пре свега Библија, затим црквени типик, а на трећем месту Достојевски'. Тада сам већ био храбрији и, сећам се, упитао сам: 'Па добро, а где су, владико, свети Оци?' Митрополит ме значајно погледа и, по свом обичају, незаборавно се осмехну“ (Керн 2018: 24). Под утицајем митрополита Антонија и других руских теолога и религијских мислилаца Јустин Поповић „Достојевског посматра као весника самосвесног повратка светим Оцима Цркве, а ради обнове културалних и друштвено-историјских токова Православља, не само у Русији““ (Лубардић 2009: 21). 
102 Ненаg Д. Плавшић: Мийройолий Анйоније Храйовищки у Краљевини СХС...

својим могућностима пружао уточиште избеглим људима припадницима братског руског народа са којим га везује заједничка православна вера и дуготрајни односи кроз историју.

Међу бројним организацијама које су помагале друштвено самоорганизовање руских избеглица истицала се Руска Православна Загранична Црква која је основана 1921. године у Сремским Карловцима и чији је први поглавар био митрополит Антоније Храповицки који је 1920. године напустио Русију и већину свог живота у изгнанству, од почетка 1921. до своје смрти 1936. године, провео у Краљевини СХС/Југославији. Нажалост, у руској емиграцији дошло је до размимоилажења у основним схватањима црквене политике. Временом, још за живота митрополита Антонија, ови односи су постали сношљивији и коначно су их решили догађаји после његове смрти. Ипак, та подвојеност је веома штетно деловала на моралне моћи и духовно јединство руских избеглица, чија борба за опстанак и очување православног бића и својих културних вредности завређује искрено дивљење.

Митрополит Антоније је и као епископ и као теолог имао изузетно важну улогу у животу Цркве. Он је наставио да се брижно односи према својој пастви и за време свог живота у егзилу као духовни поглавар доброг дела руских изгнаника. У новој средини су цењене његове велике заслуге за Цркву и за јачање руско-српских односа и доживљаван је као истакнути јерарх, писац и словенофил. Према његовој личности су се са великим поштовањем односили српски црквени и политички представници.

Митрополит Антоније Храповицки је утицао и на богословску мисао у новој средини будући да је спадао у оне руске учене теологе који су у православној богословској науци највише допринели да се она ослободи узора и утицаја који су јој туђи. Поред тога, веома добро и темељно је познавао руску књижевност, нарочито дела Достојевског која су му посебно лежала на срцу. За научно-богословску мисао митрополита Антонија је нарочито карактеристично приступање свим теоријским и практичним црквеним проблемима кроз светоотачку мисао, односно кроз богату ризницу православног духовног искуства које се разноврсно и снажно испољило у свим гранама црквеног стваралаштва. 


\section{Литература}

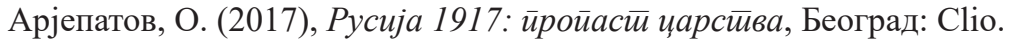

Арсењев, А. (2013), Руска емиіращија у Сремским Карловцима, Сремски Карловци: Културни центар „Карловачка уметничка радионица“- Мало историјско друштво Нови Сад.

Врангел, П. Н. (2019), Сећања, Београд: Логос-Графичар.

Ђурић, О. (1990), Руска лииеерарна Србија: иичсии, кружоци и изgања, Београд: Дечије новине-Српски фонд словенске писмености и словенских култура.

Јелачић, А. (2018), Русија и Балкан: ирреїлеg йолитичких и кулииурних веза Русије и балканских земаља, Ниш: Талија.

Јовановић, М. (1936), „Руска црква: митрополит Антоније“, у: Хришћанско gело: часойис за хришћанску кулйуру и црквени живой, свеска 5, 1936. год., 381-387.

Јовановић, М. (1996), Досељавање руских избеїлица у Краљевину СХС 1919-1924, Београд: Стубови културе.

Јовановић, М. (2008), „Руска православна загранична црква у Југославији током

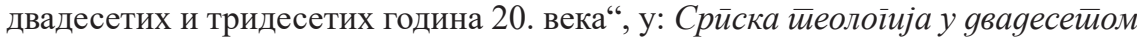
веку: истираживачки ироблеми и резулииатии књ. 3 (2008), 160-178.

Јовановић, М. (2006), Руска емиіраџија на Балкану 1920 - 1940, Београд: Чигоја штампа.

Јовановић, М. (2005), „Свештеник и друштво - ето пароле: Руска православна загранична Црква на Балкану 1920-1940“, у: Токови исйорије 3 - 4, Београд 2005, 67-100.

Качаки, Ј. (2003), Руске избеїлице у Краљевини СХС/Јуїославији: библиоірафија раgова 1920-1944: ӣокушај реконсйрукиије, Београд: Књижара Жагор-Универзитетска библиотека „Светозар Марковић“.

Керн, К. (2018), Мемоари: сећања на мийройолийа Анӣонија (Храйовицкой) и еииискойа Гаврила (Чейура), Ниш: Епархијски Управни Одбор Епархије нишке.

Лубардић, Б. (2009), Јустиин Ћелијски и Русија: йуйеви рецейције руске философије и ииеолоіије, Нови Сад: Беседа.

Пајпс, Р. (2017), Руска револуц̧ија, Београд: ИК Филип Вишњић.

Пилиповић, Р. М. (2018), Срйска йравославна ирква и руска емиіращија (1920-1940), Бања Лука-Београд: Архив Републике Српске-Архив Српске Православне Цркве-Удружење архивских радника Републике Српске.

Поповић, Ј. (1939), „Тајна личности митрополита Антонија и његов значај за православно Словенство“, у: Боїословље - орїан Православної боїословскої факулйейа у Беоіраgy, год. XIV, св. 1/1939, 40.

Поповић, J. (2007), „Он - међу њима: поводом смрти Митрополита Антонија“, $\mathrm{Ce}$ йве и жейве: чланци и мањи сиииси, Београд: Наследници Оца Јустина и Манастир Ћелије код Ваљева, 354-356.

Пузовић, В. (2012), Иситоријско-канонски асиекиии оуноса карловачке уйраве Руске заїраничне Цркве и Московске йайријаршије, необјављена докторска дисертација, Универзитет у Београду. 
104 Ненаg Д. Плавшић: Мийройолий Анйоније Храйовицки у Краљевини СХС...

Пузовић, В. (2017), Руски йуиеви срйскої боїословља: иколовање Срба на руским gуховним акаgемијама 1849-1917, Београд: Православни богословски факултет Институт за теолошка истраживања-Службени гласник.

Росић, В. (1936), Говор йайријарха срӣской Варнаве наg оgром мийройолийа Анӣонија 1936. у Беоїраgy, IntRes: http://www.vidovdan.org, преузето 25. 12. 2020.

Слијепчевић, Ђ. (2018), Исйорија срӣске йравославне цркве: књиі̆а III: за време Друїої светиской райа и йосле юеїа, Београд: Catena Mundi.

Тарасјев, А., Блажењејши Анйоније, митиройолий Кијевски и Галицки (1863-1936), IntRes: http://www.православнапородица.орг.срб, преузето: 22. 12. 2020.

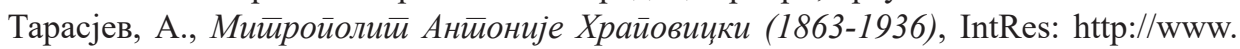
pravoslavie.ru, преузето: 22. 12. 2020.

Фирсов, С. (2008), Руска ирква уочи ирромена: крај gевеgесейих іооина ХІХ века 1918. іолина, Крагујевац: Каленић.

Храповицкий, А. (1921), Словарь к йворениям Досйоевскойо: не уолжно ойчаява$\bar{u} ъ c я$, Софія: Россійско-Болгарское книгоиздателъство.

Шаховској, Ј. (2010), Усйостиављање јеgинсиива: усйомене, Стари Бановци-Београд: Бернар.

Nenad D. Plavšić

Elementary School „Miroslav Antić“

Palić, Serbia

nenadplavsic@gmail.com

\title{
METROPOLITAN ANTHONY KHRAPOVITSKY IN KINGDOM OF SERBS, CROATS AND SLOVENES/YUGOSLAVIA 1921-1936
}

\begin{abstract}
Summary
Russian emigration is a collective noun used to describe the status of the subjects of the Russian empire, who, in the early nineteen-twenties, under the influence of fundamental political and social instability and changes in Russia, fled abroad and settled down in various countries in Europe and rest of the world. During the Civil War, perhaps as many as two million refugees poured out of Russia. Metropolitan Anthony Khrapovitsky (18631936), one of the most distinguished church dignitaries and foremost Orthodox theologian of the end of nineteenth and first half of twentieth century, shared difficult fate of Russian émigrés. Last fifteen years of his life Metropolitan Anthony spent in exile in Kingdom of Serbs, Croats and Slovenes/Yugoslavia. The aim of our work is to present that "Serbian" period of life of this eminent Russian Archbishop, whose character and works influenced certain distinguished Serbian theologians.
\end{abstract}

Keywords: Metropolitan Anthony, Russia, Kingdom of Serbs, Croats and Slovenes/ Yugoslavia, Russian Orthodox Church Outside of Russia 